\title{
HUBUNGAN LINGKAR PERGELANGAN TANGAN DENGAN KADAR GLUKOSA DARAH PADA REMAJA PUTRI USIA 15-18 TAHUN DI SMA NEGERI 6 SEMARANG
}

\author{
Riani Arifin, Binar Panunggal ${ }^{*}$ \\ Program Studi Ilmu Gizi Fakultas Kedokteran Universitas Diponegoro \\ Jl.Dr.Sutomo No.18, Semarang, Telp (024) 8453708, Email : gizifk@ undip.ac.id
}

\begin{abstract}
Background: Diabetes mellitus is a chronic disease that occurs due to pancreas unable to produce insulin or because the body can not use available insulin properly. Adolescens is the period of transition from childhood to adulthood which is a key phase of human development. Therefore control blood glucose level is necessary to detect early occurence of diabetes mellitus since adolescents. Wrist circumference is one of anthropometric measurements that is used as a predictor of diabetes mellitus. SMA Negeri 6 Semarang is one of schools where location is in Semarang city. This study aims to determine the relationship between wrist circumference with blood glucose levels in female adolescents aged 15-18 years at SMA Negeri 6 Semarang.

Method: Observational research with cross sectional design was conducted in SMA Negeri 6 Semarang with 69 students as subjects selected by consecutive sampling. Data collected include characteristic of subject, wrist circumference and blood glucose level. Wrist circumference measured by midline and blood samples were taken to measure fasting blood glucose levels. Data wrist circumferrences and blood glucose levels were analyzed using pearson test.
\end{abstract}

Result: This study found that 59,4\% of subjects had blood glucose levels at $81-90 \mathrm{mg} / \mathrm{dl}$ and 55,1\% of subjects had small wrist circumference. Wrist circumference does not related with blood glucose level $(r=-0,039 p=0,749)$.

Conclusion: there was no relationship between wrist circumference with blood glucose levels in female adolescents aged 15-18 years at SMA Negeri 6 Semarang.

Keyword: wrist circumference; blood glucose level; diabetes mellitus

\begin{abstract}
ABSTRAK
Latar Belakang : Diabetes melitus merupakan penyakit kronis yang disebabkan karena pankreas tidak mampu memproduksi insulin atau karena tubuh tidak dapat menggunakan insulin yang ada. Untuk mendeteksi dini kejadian diabetes melitus perlu dilakukan kontrol kadar glukosa darah sejak remaja. Lingkar pergelangan merupakan salah satu antropometri yang digunakan sebagai prediktor diabetes melitus. SMA Negeri 6 Semarang merupakan salah satu sekolah yang berada di kota Semarang. Penelitian ini bertujuan untuk mengetahui hubungan lingkar pergelangan tangan dengan kadar glukosa darah pada remaja putri usia 15-18 tahun di SMA Negeri 6 Semarang.

Metode : penelitian Observasional dengan desain cross sectional, bertempat di SMA Negeri 6 Semarang dengan jumlah sampel 69 subjek yang dipilih dengan consecutive sampling. Data yang dikumpulkan meliputi karakteristik subjek, lingkar pergelangan tangan dan kadar glukosa darah puasa. Lingkar pergelangan tangan diukur menggunakan midline. Pengambilan sampel darah dilakukan untuk pengukuran kadar glukosa darah puasa. Analisis bivariat dilakukan menggunakan uji korelasi pearson.

Hasil : Pada penelitian ini ditemukan sebanyak 59,4\% subjek mempunyai kadar glukosa darah pada range $81-90$ $\mathrm{mg} / \mathrm{dl}$ dan 55,1\% lingkar pergelangan tangan subjek termasuk dalam kategori kecil. Lingkar pergelangan tangan tidak berhubungan dengan kadar glukosa darah $(r=-0,039 p=0,749)$.

Simpulan : Tidak terdapat hubungan antara lingkar pergelangan tangan dengan kadar glukosa darah pada remaja putri usia 15-18 tahun di SMA Negeri 6 Semarang
\end{abstract}

Kata kunci : Lingkar pergelangan tangan; kadar glukosa darah; diabetes melitus

\section{PENDAHULUAN}

Diabetes melitus merupakan penyakit kronis yang disebabkan karena pankreas tidak mampu memproduksi insulin atau karena tubuh tidak dapat menggunakan insulin yang ada. ${ }^{1}$ Kejadian diabetes melitus secara global meningkat karena pertumbuhan populasi, penuaan, urbanisasi, aktifitas fisik yang kurang dan peningkatan prevalensi obesitas. ${ }^{2}$ Berdasarkan hasil RISKESDAS tahun 2013 angka kejadian diabetes di Indonesia mengalami peningkatan dari $1,1 \%$ pada tahun 2007 menjadi 2,1\% pada tahun 2013 . Pada tahun 2010 kota Semarang merupakan daerah dengan kejadian diabetes melitus tipe 2 tertinggi di Jawa Tengah prevalensinya sebesar $1,66 \% .^{3}$

Pada umumnya usia penderita diabetes melitus tipe 2 yaitu lebih dari 40 tahun, namun pada pertengahan tahun 1990 kejadian diabetes melitus tipe 2 pada remaja meningkat secara global. Pada tahun 2008 prevalensi diabetes melitus tipe 2 pada remaja di Amerika Serikat meningkat tiga kali lipat meskipun kejadian obesitas tidak meningkat dengan

\footnotetext{
${ }^{*}$ Penulis Penanggungjawab
} 
kejadian 2,3-50,9 per 100.000 populasi pada remaja usia 15-19 tahun. $^{4}$

Diabetes melitus tipe-2 yang tidak terdeteksi dan ditangani sejak dini dapat mengakibatkan komplikasi jangka panjang. Komplikasinya dapat berupa kerusakan mikrovaskuler dan makrovaskuler. ${ }^{1}$ Perlu dilakukan upaya preventif untuk mencegah peningkatan prevalensi dan komplikasi agar kejadian diabetes melitus diketahui lebih awal. Mengontrol kadar glukosa darah merupakan salah satu upaya untuk mencegah dan mendeteksi dini kejadian diabetes melitus. ${ }^{5}$ Sejumlah studi telah mengkonfirmasi bahwa pengukuran kadar glukosa darah puasa dapat lebih sensitif untuk mendiagnosa diabetes pada populasi umum. ${ }^{6}$

Pengukuran antropometri juga digunakan sebagai salah satu parameter untuk mendeteksi suatu penyakit karena sensitif terhadap perubahan fisik yang berkaitan dengan penyakit tertentu. Lingkar pergelangan tangan merupakan pengukuran antropometri skeletal frame size yang sederhana dan baru-baru ini telah diteliti kaitannya dengan insulin pada anak dan remaja obesitas. ${ }^{7}$ Penelitian di Italia pada tahun 2011 menunjukkan bahwa lingkar pergelangan tangan yang diukur menggunakan pita midline berhubungan secara signifikan dengan kadar glukosa darah puasa pada anak dan remaja obesitas. Menurut penelitian tersebut bagian lingkar pergelangan tangan yang berhubungan dengan kadar glukosa darah puasa adalah jaringan tulang dari pergelangan tangan setelah dilakukan pengukuran lanjutan pada subjek menggunakan metode Magnetic Resonance Imaging. ${ }^{7}$ Penelitian lain yang dilakukan di Iran pada tahun 2001 dan penelitian lanjutan pada tahun 2011 menunjukkan bahwa lingkar pergelangan tangan berhubungan secara signifikan dengan kejadian diabetes melitus dan dapat menjadi prediktor diabetes melitus dan sindrom metabolik pada populasi dewasa. ${ }^{8}$

Penelitian tentang hubungan lingkar pergelangan tangan dengan kadar glukosa darah pada remaja putri usia 15-18 tahun atau yang berstatus sebagai pelajar Sekolah Menengah Atas (SMA) belum pernah dilakukan. SMA Negeri 6 Semarang merupakan sekolah yang termasuk dalam wilayah kota Semarang yang merupakan kota dengan prevalensi diabetes melitus tipe 2 tertinggi di Jawa tengah pada tahun 2010 dan belum pernah dilakukan penelitian tentang pengukuran lingkar pergelangan tangan dan kadar glukosa darah.

Berdasarkan latar belakang tersebut maka peneliti tertarik untuk meneliti hubungan lingkar pergelangan tangan dengan kadar glukosa darah pada remaja putri usia 15-18 tahun di SMA Negeri 6 Semarang.

\section{METODA}

Penelitian ini dilaksanakan di SMA Negeri 6 Semarang Provinsi Jawa Tengah. Pengambilan data dilakukan pada bulan September 2014. Ruang lingkup penelitian ini termasuk ke dalam bidang gizi masyarakat. Penelitian ini merupakan penelitian observasional analitik dengan desain cross sectional.

Populasi target adalah seluruh pelajar putri SMA di Semarang. Populasi terjangkau adalah seluruh pelajar putri di SMA Negeri 6 Semarang. Sampel penelitian ini adalah seluruh pelajar putri di SMA Negeri 6 Semarang yang memenuhi kriteria inklusi dan eksklusi penelitian. Teknik pengambilan sampel menggunakan teknik consecutive sampling. Sampel yang didapat sebanyak 69 subjek berdasarkan rumus besar sampel tunggal untuk estimasi proporsi suatu populasi. ${ }^{9}$ Kriteria inklusi meliputi sampel berjenis kelamin perempuan dengan usia 15-18 tahun, tidak sedang mengonsumsi obat penurun gula darah, tidak terdapat kelainan/luka pada pergelangan tangan yang dapat mengganggu pengukuran lingkar pergelangan tangan, serta bersedia menjadi subjek penelitian. Kriteria eksklusi penelitian adalah tidak datang saat pengambilan sampel darah dan subjek mengundurkan diri dari penelitian.

Variabel terikat adalah kadar glukosa darah. Pengukuran kadar glukosa darah subjek dilakukan dengan menilai kadar glukosa darah puasa yang dilakukan oleh petugas Laboratorium Ideal Semarang yang diambil melalui pembuluh darah vena setelah sebelumnya subjek melakukan puasa selama 8-12 jam (mulai pukul $22.00-08.00$ ). Pengukuran kadar glukosa darah dilakukan dengan menggunakan metode enzimatik. Hasil pengukuran kadar glukosa darah puasa dengan satuan $\mathrm{mg} / \mathrm{dl}$ dan skala rasio. Data kadar glukosa darah puasa disajikan dalam range yaitu $60-70 \mathrm{mg} / \mathrm{dl}, 71-80$ $\mathrm{mg} / \mathrm{dl}, 81-90 \mathrm{mg} / \mathrm{dl}, 91-100 \mathrm{mg} / \mathrm{dl}$.

Variabel bebas adalah lingkar pergelangan tangan. Pengukuran lingkar pergelangan tangan dilakukan dalam posisi duduk tenang dengan lengan tangan kanan diletakkan di alas datar dan telapak tangan telungkup. Lingkar pergelangan tangan diukur dengan pita midline secara horizontal yang diletakkan pada tonjolan ulna bagian distal melingkari pergelangan tangan. ${ }^{7}$ Dilakukan pengukuran lingkar pergelangan tangan sebanyak 3 kali oleh enumerator yang sama untuk 
mendapatkan nilai rata-rata. Hasil pengukuran lingkar pergelangan tangan dengan satuan sentimeter $(\mathrm{cm})$ dan skala rasio. Kategori lingkar pergelangan tangan untuk perempuan dibagi menjadi tiga yaitu Kecil jika subyek dengan tinggi badan $<155 \mathrm{~cm}$ mempunyai lingkar pergelangan tangan $<14 \mathrm{~cm}$, subyek dengan tinggi badan 155 $163 \mathrm{~cm}$ mempunyai lingkar pergelangan tangan $<15,2 \mathrm{~cm}$, subyek dengan tinggi badan $>163 \mathrm{~cm}$ mempunyai lingkar pergelangan tangan $<15,9 \mathrm{~cm}$; Kategori sedang jika subyek dengan tinggi badan $<155 \mathrm{~cm}$ mempunyai lingkar pergelangan tangan 14-14,6 cm, subyek dengan tinggi badan 155-163 $\mathrm{cm}$ mempunyai lingkar pergelangan tangan 15,2$15,9 \mathrm{~cm}$, subyek dengan tinggi badan $>163 \mathrm{~cm}$ mempunyai lingkar pergelangan tangan 15,9-16,5 $\mathrm{cm}$; Kategori besar jika subyek dengan tinggi badan $<155 \mathrm{~cm}$ mempunyai lingkar pergelangan tangan $>14,6 \mathrm{~cm}$, subyek dengan tinggi badan $155-163 \mathrm{~cm}$ mempunyai lingkar pergelangan tangan $>15,9 \mathrm{~cm}$, subyek dengan tinggi badan $>163 \mathrm{~cm}$ mempunyai lingkar pergelangan tangan $>16,5 \mathrm{~cm} .{ }^{10}$

Data yang dikumpulkan meliputi nama, usia, ada/tidaknya riwayat penyakit DM pada orang tua, ada/tidaknya riwayat mengkonsumsi obat penurun gula darah yang diperoleh melalui wawancara, data berat badan, tinggi badan, status gizi, lingkar pergelangan tangan yang diperoleh melalui pengukuran antropometri dan data kadar glukosa darah puasa yang diperoleh dari hasil laboratorium. Subjek dikategorikan mempunyai riwayat DM pada orang tua jika salah satu atau kedua orang tua dari subjek menderita diabetes melitus. Status gizi subjek dikategorikan berdasarkan Indeks Massa Tubuh per usia menurut WHO 2007. Status gizi subjek dikategorikan Kurus jika Zscore < -2SD, Normal jika Zscore $\geq-2 S D$ s/d $+1 \mathrm{SD}$ dan Overweight Jika Zscore > +1SD. ${ }^{11}$

Analisis data dilakukan dengan menggunakan program SPSS Windows 17.0. Analisa univariat dilakukan dengan memasukkan data secara terpisah dalam tabel distribusi frekuensi untuk mendeskripsikan data usia, status gizi, riwayat DM keluarga, lingkar pergelangan tangan dan kadar glukosa darah puasa. Sebaran data dapat diketahui normalitasnya melalui uji Kolmogorov Smirnov dengan nilai kemaknaan $\mathrm{p}>0,05$ untuk sampel lebih dari 50 responden. Analisis bivariat dilakukan untuk melihat hubungan antara dua variabel, yaitu variabel bebas dan variabel terikat dengan uji korelasi Pearson karena data berdistribusi normal.

\section{HASIL PENELITIAN \\ Karakteristik Subjek}

Penelitian telah dilakukan di SMA Negeri 6 Semarang dengan subjek pelajar putri. Sampel yang didapatkan sebesar 69 orang berusia 15 sampai 18 tahun. Karakteristik subjek penelitian dapat dilihat pada tabel 1.

Tabel 1. Karakteristik subjek menurut usia, IMT, lingkar pergelangan tangan dan kadar glukosa darah puasa.

\begin{tabular}{lcc}
\hline Variabel & n & mean \pm SD \\
\hline Usia (tahun) & 69 & $16 \pm 0,8$ \\
Indeks Massa Tubuh $\left(\mathrm{kg} / \mathrm{m}^{2}\right)$ & 69 & $20,27 \pm 2,9$ \\
Lingkar pergelangan tangan $(\mathrm{cm})$ & 69 & $14,56 \pm 0,7$ \\
Kadar glukosa darah puasa $(\mathrm{mg} / \mathrm{dl})$ & 69 & $83,27 \pm 6,1$ \\
\hline
\end{tabular}

Distribusi frekuensi subjek penelitian berdasarkan lingkar pergelangan tangan dan kadar glukosa darah usia, Status gizi, Riwayat diabetes melitus keluarga, puasa dapat dilihat pada tabel 2.

Tabel 2. Distribusi frekuensi subjek berdasarkan usia, Status gizi, Riwayat diabetes melitus keluarga, lingkar pergelangan tangan dan kadar glukosa darah puasa

\begin{tabular}{|c|c|c|c|}
\hline Variabel & & $\mathrm{n}$ & Persentase \\
\hline \multicolumn{4}{|l|}{ Usia } \\
\hline 15 tahun & & 21 & $30,4 \%$ \\
\hline 16 tahun & & 30 & $43,5 \%$ \\
\hline 17 tahun & & 15 & $21,7 \%$ \\
\hline 18 tahun & & 3 & $4,3 \%$ \\
\hline \multicolumn{4}{|l|}{ Status Gizi } \\
\hline Kurus & $=<-2 \mathrm{SD}$ & 5 & $7,2 \%$ \\
\hline Normal & $=\geq-2 S D$ s $/ d+1 S D$ & 54 & $78,3 \%$ \\
\hline Overweight & $=>+1 \mathrm{SD}$ & 10 & $14,5 \%$ \\
\hline \multicolumn{4}{|c|}{ Riwayat DM Keluarga } \\
\hline $\mathrm{Ya}$ & & 24 & $34,8 \%$ \\
\hline Tidak & & 45 & $65,2 \%$ \\
\hline
\end{tabular}




\begin{tabular}{llr}
\hline Lingkar Pergelangan tangan & & \\
Kecil & 38 & $55,1 \%$ \\
Sedang & 18 & $26,1 \%$ \\
Besar & 13 & $18,8 \%$ \\
Kadar glukosa darah puasa & & \\
$60-70 \mathrm{mg} / \mathrm{dl}$ & 2 & $2,9 \%$ \\
$71-80 \mathrm{mg} / \mathrm{dl}$ & 19 & $27,5 \%$ \\
$81-90 \mathrm{mg} / \mathrm{dl}$ & 41 & $59,4 \%$ \\
$91-100 \mathrm{mg} / \mathrm{dl}$ & 7 & $10,1 \%$ \\
\hline
\end{tabular}

Tabel 2. Menunjukkan usia subjek yang paling banyak adalah usia 16 tahun sebanyak $43,5 \%$. Status gizi subjek yang paling banyak adalah status gizi normal dengan persentase sebanyak $78,3 \%$. Terdapat $65,2 \%$ subjek yang tidak mempunyai riwayat DM pada keluarga. Lingkar pergelangan tangan subjek termasuk dalam kategori kecil sebesar $55,1 \%$. Kadar glukosa darah puasa subjek sebanyak $59,4 \%$ termasuk dalam range 81 $90 \mathrm{mg} / \mathrm{dl}$. Data kadar glukosa darah tidak disajikan dalam kategori $<100 \mathrm{mg} / \mathrm{dl}$ dan $\geq 100 \mathrm{mg} / \mathrm{dl}$ menurut Internasional Diabetes Federation ${ }^{12}$ karena semua data kadar glukosa darah puasa dalam penelitian ini $<100 \mathrm{mg} / \mathrm{dl}$, maka disajikan dalam bentuk range.

Tabel 3. Distribusi frekuensi kadar glukosa darah subjek berdasarkan status gizi dan Riwayat DM keluarga

\begin{tabular}{|c|c|c|c|c|c|c|c|c|}
\hline & \multicolumn{8}{|c|}{ Kadar glukosa darah puasa } \\
\hline & \multicolumn{2}{|c|}{$60-70 \mathrm{mg} / \mathrm{dl}$} & \multicolumn{2}{|c|}{$71-80 \mathrm{mg} / \mathrm{dl}$} & \multicolumn{2}{|c|}{$81-90 \mathrm{mg} / \mathrm{dl}$} & \multicolumn{2}{|c|}{$91-100 \mathrm{mg} / \mathrm{dl}$} \\
\hline & $\mathrm{n}$ & $\%$ & $\mathrm{n}$ & $\%$ & $\mathrm{n}$ & $\%$ & $\mathrm{n}$ & $\%$ \\
\hline \multicolumn{9}{|l|}{ Status Gizi } \\
\hline Kurus & 0 & $0 \%$ & 1 & $20,0 \%$ & 3 & $60 \%$ & 1 & $20 \%$ \\
\hline Normal & 1 & $1,9 \%$ & 13 & $24,1 \%$ & 34 & $63 \%$ & 6 & $11 \%$ \\
\hline Overweight & 1 & $10,0 \%$ & 5 & $50,0 \%$ & 4 & $40 \%$ & 0 & $0 \%$ \\
\hline \multicolumn{9}{|l|}{ Riwayat DM } \\
\hline Ya & 0 & $0 \%$ & 10 & $41,7 \%$ & 12 & $50 \%$ & 2 & $8,3 \%$ \\
\hline Tidak & 2 & $4,4 \%$ & 9 & $20 \%$ & 29 & $64,4 \%$ & 5 & $11,1 \%$ \\
\hline
\end{tabular}

Tabel 3 menunjukkan distribusi kadar glukosa darah berdasarkan status gizi dan riwayat DM pada keluarga. Menurut tabel tersebut sebanyak $60 \%$ subjek dengan status gizi kurus mempunyai kadar glukosa darah puasa dalam range 81-90 $\mathrm{mg} / \mathrm{dl}$. Sejumlah $63 \%$ subjek dengan status gizi normal juga mempunyai kadar glukosa darah puasa dalam range $81-90 \mathrm{mg} / \mathrm{dl}$. Sedangkan 50\% subjek dengan status gizi overweight mempunyai kadar glukosa darah puasa dalam range 71-80 mg/dl. Distribusi frekuensi subjek yang mempunyai riwayat dan tidak mempunyai riwayat DM pada keluarga sebanyak 50\% dan 64,4\% kadar glukosa darah puasanya berada dalam range 81-90 mg/dl.

Hubungan Lingkar Pergelangan tangan dengan kadar glukosa darah

Berdasarkan analisis pearson menunjukkan tidak terdapat hubungan antara lingkar pergelangan tangan dengan kadar glukosa darah $(\mathrm{r}=-0,039, p=0,749)$.

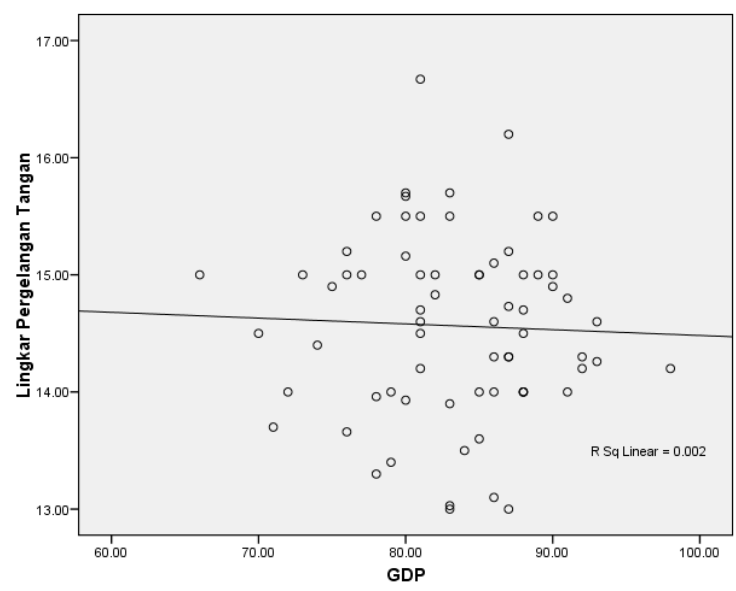

Gambar 1. Hubungan lingkar pergelangan tangan dengan kadar glukosa darah

\section{PEMBAHASAN}

Subjek penelitian ini sebanyak 69 pelajar SMA putri dengan usia 15-18 tahun. Pada penelitian ini menggunakan subjek usia remaja karena telah diketahui bahwa beberapa parameter antropometri yang diukur pada subjek lanjut usia relevansinya lebih rendah dibandingkan dengan subjek nonlansia karena dalam proses penuaan terjadi perubahan fisiologi. 
Beberapa pengukuran lingkar tubuh telah diteliti kaitannya dengan diabetes. Namun hanya beberapa penelitian yang menganalisis antropometri lingkar pergelangan tangan dengan diabetes melitus. Sebuah penelitian yang dilakukan oleh Capizzi di Italia pada 477 anak dan remaja overweight dan obesitas menunjukkan bahwa lingkar pergelangan tangan berhubungan dengan insulin dan kadar glukosa darah. ${ }^{7}$ Penelitian yang dilakukan oleh Jahangiri di Iran dengan 6393 subjek (3677 wanita, 2716 laki-laki) menunjukkan lingkar pergelangan tangan berhubungan secara signifikan dengan kejadian diabetes melitus. Pada penelitian tersebut lingkar pergelangan tangan berhubungan dengan kadar glukosa darah puasa pada subjek lakilaki dan perempuan. ${ }^{8}$ Berdasarkan hasil penelitian ini menunjukkan bahwa tidak terdapat hubungan antara lingkar pergelangan tangan dengan kadar glukosa darah pada remaja putri usia 15-18 tahun.

Hasil penelitian ini bertentangan dengan penelitian yang dilakukan di Italia. Tidak adanya hubungan dalam penelitian ini dapat disebabkan karena perbedaan subjek yang digunakan. Pada penelitian Capizzi menggunakan subjek anak dan remaja dengan status gizi overweight dan obesitas. Telah diketahui bahwa status gizi obesitas menjadi faktor utama berkembangnya resistensi insulin pada anak dan remaja. Anak dan remaja dengan status gizi obesitas mempunyai sensitivitas insulin $40 \%$ lebih rendah dibandingkan dengan anak nonobesitas. Sehingga kemampuan insulin menurunkan konsentrasi glukosa darah dengan cara menstimulasi pemakaian glukosa di jaringan otot, lemak dan menekan produksi glukosa oleh hati menurun. ${ }^{13}$ Sedangkan pada penelitian ini sebanyak $78,3 \%$ subjek mempunyai status gizi normal. Hal tersebut yang mungkin menyebabkan kadar glukosa darah puasa subjek pada penelitian ini dalam kategori normal.

Menurut penelitian Capizzi, bagian dari lingkar pergelangan tangan yang berkaitan dengan insulin dan kadar glukosa darah adalah jaringan tulang yang dianalisis berdasarkan hasil uji Magnetic Resonance Imaging (MRI). ${ }^{7}$ Pada penelitian tersebut dapat membedakan area dari jaringan tulang dan jaringan adiposa serta menganalisis hubungannya dengan insulin dan kadar glukosa darah. Pada penelitian ini tidak dilakukan uji MRI sehingga tidak dapat menganalisis hubungan jaringan tulang di lingkar pergelangan tangan dengan kadar glukosa darah dan tidak dapat membedakan besarnya ukuran lingkar pergelangan tangan karena area jaringan tulang atau jaringan adiposa.
Lingkar pergelangan tangan merupakan pengukuran antropometri skeletal frame size tanpa terpengaruh oleh jaringan lemak. Hubungan lingkar pergelangan tangan dengan kadar glukosa darah dijelaskan melalui peran insulin yang berkaitan dengan peningkatan massa tulang. Insulin-like growth factor 1 (IGF-1) merupakan insulin yang bertindak sebagai faktor pertumbuhan mempunyai peran dalam aktivitas osteoblas. IGF-1 mempunyai $40 \%$ struktur asam amino yang sama dengan insulin yang berperan dalam metabolisme glukosa. Hal tersebut yang mendasari bahwa insulin menjadi penghubung antara metabolisme glukosa dan jaringan tulang. ${ }^{14,15}$

Hasil penelitian ini juga bertentangan dengan penelitian yang dilakukan Shao Yuan di Taiwan yang menyatakan bahwa lingkar pergelangan tangan berhubungan dengan kadar glukosa darah pada anak-anak usia 8-12 tahun dengan nilai $\mathrm{p}<0,001 .{ }^{16}$ Tidak adanya hubungan pada penelitian ini dapat disebabkan karena jumlah subjek yang lebih sedikit dibandingkan dengan penelitian yang dilakukan oleh Shao Yuan dengan jumlah subjek penelitian sebanyak 2215 dengan 1189 subjek laki-laki dan 1026 perempuan serta pada penelitian tersebut didapatkan kadar glukosa darah puasa yang bervariasi. Sedangkan pada penelitian ini hanya terdapat 69 subjek dengan kadar glukosa darah dalam kategori normal. Pengukuran lingkar pergelangan tangan pada penelitian Shao Yuan menggunakan pita midline sama seperti penelitian ini.

Penelitian yang dilakukan di Iran oleh Jahangiri pada tahun 2001 dan penelitian lanjutan pada tahun 2011 menunjukkan bahwa lingkar pergelangan tangan berhubungan dengan kadar glukosa darah puasa pada subjek laki-laki dan wanita dewasa. Menurut penelitian tersebut kejadian diabetes melitus meningkat $50 \%$ setiap 1 $\mathrm{cm}$ peningkatan lingkar pergelangan tangan pada wanita. Setelah 8,8 tahun penelitian awal, cut off lingkar pergelangan tangan yang dapat memprediksi kejadian diabetes melitus pada wanita yaitu $15.7 \mathrm{~cm}$ dengan sensitivitas 80,6\% dan spesifisitas 53\%. ${ }^{8}$ Namun, pada penelitian tersebut tidak diketahui jaringan dari lingkar pergelangan tangan yang berhubungan dengan kejadian diabetes karena pengukuran lingkar pergelangan tangan hanya menggunakan pita. Hasil penelitian Jahangiri tersebut berbeda dengan penelitian ini karena perbedaan usia subjek dengan rata-rata usia 42 tahun pada subjek wanita dan usia 44 tahun pada subjek laki-laki. Pada penelitian ini menggunakan subjek yang masih dalam masa pertumbuhan yaitu 15-18 tahun dan tidak menggunakan subjek dengan 
usia diatas 40 tahun karena subjek dengan usia lanjut berkaitan dengan gangguan kerja insulin dalam mencapai sel target. ${ }^{87}$

\section{SIMPULAN}

Tidak terdapat hubungan antara lingkar pergelangan tangan dengan kadar glukosa darah pada remaja putri usia 15-18 tahun di SMA Negeri 6 Semarang.

\section{SARAN}

Perlu dilakukan analisis lingkar pergelangan tangan menggunakan Magnetic Resonance Imaging agar diketahui gambaran area jaringan tulang dan adiposa dari subjek serta dapat menganalisis hubungannya dengan kadar glukosa darah.

\section{DAFTAR PUSTAKA}

1. World Health Organization. Definition and Diabetes Mellitus and Intermediate Hyperglycemia. 2006

2. Wild Sarah, Roglic Gojka,Green Anders, Sicree Richard, King Hilary. Global Prevalence of Diabetes : Estimates for the year 2000 and projections for 2030. Diabetes care 2004;27:104753

3. Departemen Kementerian Kesehatan. Penyajian Pokok-Pokok Hasil Riset Kesehatan Dasar 2013. Jakarta:Badan Penelitian dan Pengembangan Kesehatan Kementerian Kesehatan, 2013

4. Reinehr T. Type 2 diabetes mellitus in children and adolescents.World J Diabetes 2013; 4(6): 270-81

5. Hardiman Shinta L, Bernanthus Intan Nevita, Rustatu Puspa K, Susiyanti Eva. Waist Circumference as a Predictor for Blood glucose levels in adults. Univ Med 2009; 28(2):77-82

6. American Diabetes Association. Standards of medical care in diabetes. Diabetes care 2014 January; 37 (1): 14-80

7. Capizzi Marco, Leto Gaetano, Petrone Antonio, Zampetti Simona, Papa Raffaele Edo, Osimani Marcello, et al. Wrist circumference is a clinical marker of insulin resistance in overweight and obese children and adolescents. J Circulation 2011 April 11;123:1757-62

8. Noudeh Younes Jahangiri, Hadaegh, Vatankhah Nasibeh, Momenan Amir Abbas, Saadat Navid, Kha`lili Davood, et al. Wrist circumference as a novel predictor of diabetes and prediabetes: results of cross sectional and 8.8-year follow-up studies. J Clin Endocrin Metab 2013 February; 98(2):777-84

9. Satroasmoro Sudigdo, Ismael Sofyan. Dasar-dasar Metodologi Penelitian Klinis. Dalam : Madiyono Bambang, $\mathrm{Mz} \mathrm{S}$ Moeslichan, Sastroasmoro Sudigdo, Budiman I, Purwanto S Harry. Perkiraan Besar Sampel. Edisi keempat. Jakarta. Sagung Seto; 2011.p.349;17
10. National Institute of Health (US). Calculating Body Frame Size. Washington: 2012

11. World Health Organization. Growth Reference 519 years. Geneva: WHO, 2007

12. Alberti George, Zimmet Paul, kaufman Francine, et al. The IDF Consensus Definition of The Metabolic Syndrome in Children and Adolescent; 2007 October; Brussels, Belgium:IDF;2007

13. Chiarelli Francesco, Marcovecchio Maria Loredana. Insulin resistance and obesity in childhood. Eur J Endocrinol 2008. 159:67-74

14. Fulzele K, Riddle RC, DiGirolamo DJ, Cao X, Wan C, Chen D, Faugere MC, Aja S, Hussain MA, Brüning JC, Clemens TL. Insulin receptor signaling in osteoblasts regulates postnatal bone acquisition and body composition. Cell. 2010;23:142:309-19.

15. Ferron Mathieu, Wei Jianwen, Yoshizawa Tatsuya, Fattore Andrea Del, Depinho Ronald A, Tetti Anna, et al. Insulin Signaling in Osteoblast integrates bone remodelling and energy metabolism. J Cell 2010 July 23; 142:296-308

16. Chuang Shao Yuan, Pan Wen Harn. Predictability and Implications of anthropometric indices for metabolic abnormalities in children: nutrition and health survey in Taiwan Children, 2001-2002. Asia Pac J Clin Nutr 2009;18(2):272-79

17. Fulop T, Larbi A, Douziech N. Insulin Receptor and Ageing. Pathol Biol(Paris). 2003;51:574-80. 